This item was submitted to Loughborough's Research Repository by the author.

Items in Figshare are protected by copyright, with all rights reserved, unless otherwise indicated.

\title{
Modern forms of international working
}

PLEASE CITE THE PUBLISHED VERSION

PUBLISHER

(c) Routledge

VERSION

AM (Accepted Manuscript)

LICENCE

CC BY-NC-ND 4.0

\section{REPOSITORY RECORD}

Mayrhofer, W., Paul Sparrow, and Angelika Zimmermann. 2019. "Modern Forms of International Working". figshare. https://hdl.handle.net/2134/9872. 
This item was submitted to Loughborough's Institutional Repository (https://dspace.lboro.ac.uk/) by the author and is made available under the following Creative Commons Licence conditions.

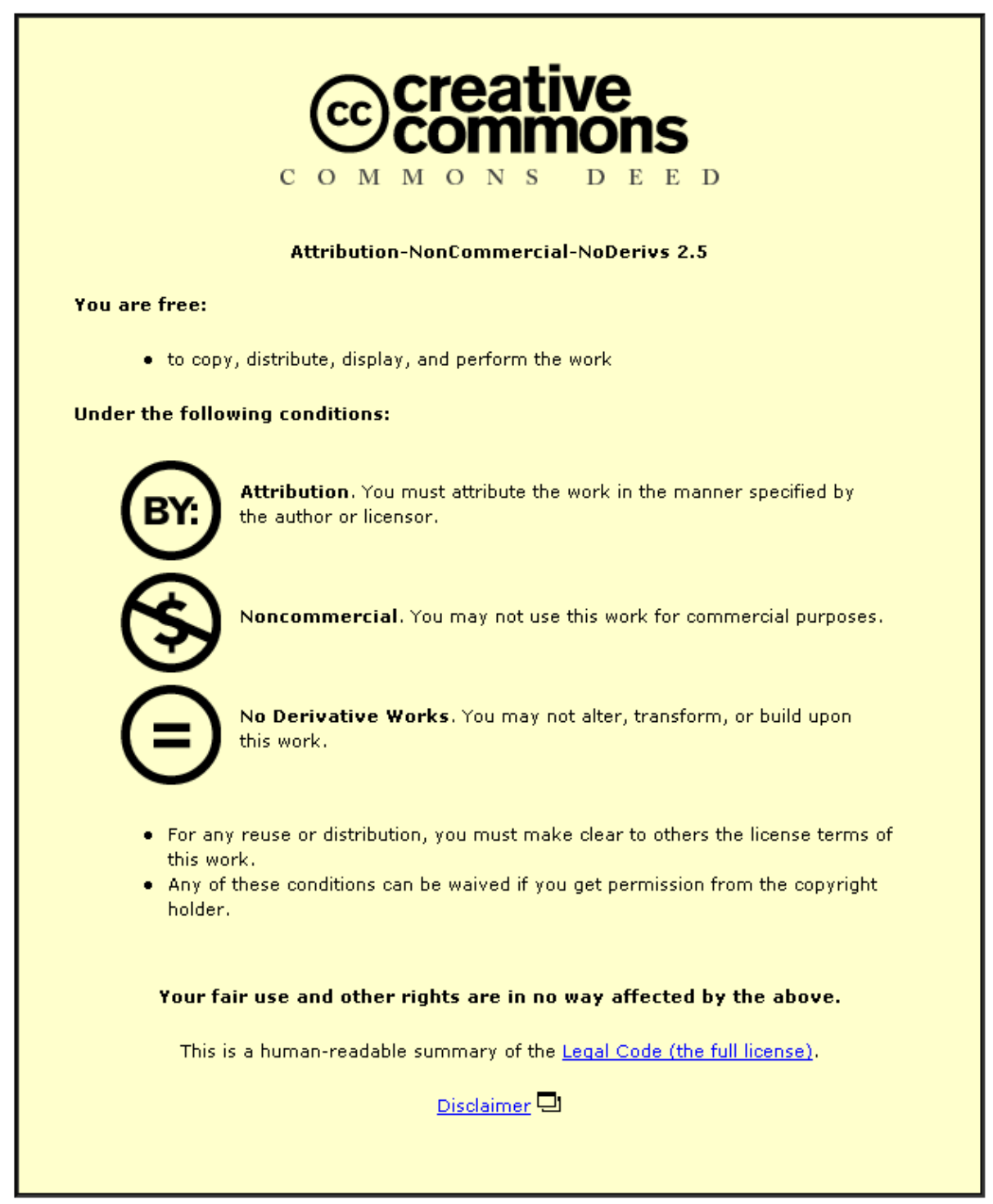

For the full text of this licence, please go to: http://creativecommons.org/licenses/by-nc-nd/2.5/ 
For C. Brewster, M. Dickmann and P. Sparrow (Eds.) (2007)

International HRM: Contemporary Issues in Europe. London: Routledge

CURRENT WORDS version 94: Total 8548

\section{Chapter 12}

\section{New forms of International HRM}

Wolfgang Mayrhofer, Paul Sparrow and Angelika Zimmermann

\section{CHAPTER OBJECTIVES}

- To explain the demand and supply factors that have led to new forms of international working beyond expatriation

- To outline some of the main characteristics and consequences for organisations of these different forms of international working

- To provide an organisational example of best practice in managing issues of intercultural training across these more diverse forms of working

- To identify the factors that enable us to determine whether these developments represent a fragmentation of international resourcing or a coherent strategy

- To signal some of the issues that should form a future research agenda around these developments 


\section{INTRODUCTION}

International assignments - traditionally: the management of expatriates and various aspects of the expatriation process - are an established element of international human resource management (IHRM) in academia and practice. Consequently, related literature flourishes. It ranges from overview and textbook contributions about expatriates and global leaders (Dowling \& Welch, 2004; Mendenhall, Kühlmann, \& Stahl, 2000) to detailed analyses and recommendations about different elements of expatriation such as recruitment and selection (Guthrie, Ash, \& Stevens, 2003), adaptation and acculturation processes (Ward, 1996) or repatriation (Linehan \& Mayrhofer, 2005). In practice, expatriation is a substantial part of IHRM activities, too. A recent survey (GMAC-Global-Relocation-Services, 2005) suggests that in $200547 \%$ of the organisations surveyed expected growth in the size of their expatriate workforce.

However, there have been shifts in both supply and demand factors that have brought substantial changes in the area of working internationally. A number of other forms of international working with labels such as flexpatriates, frequent travellers, or international commuters (Harris, Brewster, \& Erten, 2005) have gained importance. Despite some differences, they have one thing in common: they deviate from classic expatriation and the respective expatriation cycle. Three influencing factors are responsible for the emergence of these new forms. 
First, a changing macro-environment creates new demands for working beyond national borders. Globalised business processes, efforts to create markets with few barriers for business transactions through legal frameworks such as GATT, or emerging supranational institutions such as the European Union (EU) have changed the economic situation and stimulated exchange of goods, services and people world wide. Supporting international mobility is on the political agenda in many countries. For example, in 2002 the European Commission proposed a plan to make it easier for Europe's workers to find and move to jobs anywhere around the continent. The EU also proposed making the tax, pension and social security systems across the EU more compatible and to increase immigration from outside the EU. Programs such as SOCRATES, Leonardo da Vinci or TEMPUS support European exchange of people and create informal networks of understanding and contacts and lead to insight into different ways of living.

Second, organisations create additional demand for an international workforce themselves. For Salt and Millar (2006), three demand factors have fuelled growth in new forms of international working: the need for skilled international employees to help build new international markets; temporary and short term access to specialised talent in sending countries to assist the execution of overseas projects; and the need for highly mobile elites of management to perform boundary-spanning roles to help build social networks and facilitate the exchange of knowledge. Businesses operating across national borders see individuals' willingness to follow the work demand across national borders as part of the implicit - and often explicit - work contract. In a similar way, project dominated organisational forms often require working internationally (Harris, 2000). 
Third, career concepts and profiles of individuals interested in working internationally have changed substantially, due to changing individual concepts of work and career in general, e.g. alternatives to traditional work arrangements such as boundaryless (Arthur \& Rousseau, 1996) or protean careers (Hall \& Mirvis, 1996), a greater diversity of work arrangements beyond 40 hours/5 days a week, and a variety of different career patterns such as patchwork or spiral careers (Brousseau, Driver, Eneroth, \& Larsson, 1996). The profile of the people working abroad has changed and now includes:

- a rising number of individuals from outside the headquarters country such as 'third-country nationals', i.e. not from the home or the host country,

- inpatriates, i.e. people brought into headquarters; better education of people working abroad;

- an increasing number of women who still face substantial barriers in their international careers;

- the more frequent occurrence of dual-career couples where both partners pursue an occupational career of their own and during an international assignment of one of them not merely act as 'trailing spouses'

Summarizing this, Briscoe and Schuler (2004: 223) observe that the definition of "international employee" inside organisations has continued to expand: “... the tradition of referring to all international employees as expatriates - or even international assignees - falls short of the need for international HR practitioners to understand the options available... and fit them to evolving international business strategies". There are 
now a wide range of options that can enable the global resourcing of work in organisations.

In this chapter, in order to understand the context of resourcing work on an international basis, we include research on what at first sight appears to be a fragmentary group of individuals, ranging from: contract expatriates; assignees on short term or intermediate term foreign postings; permanent cadres of global managers; international commuters; employees utilised on long-term business trips; international transferees moving from one subsidiary to another; self-initiated movers who live in a third country but are willing to work for a multinational; virtual international employees active in crossborder project teams; immigrants actively and passively attracted to a national labour market; domestically based employees in a service centre but dealing with overseas customers, suppliers and partners on a regular basis; and skilled individuals working in geographically remote centres of excellence serving global operations. The core of this chapter will outline their major characteristics and analyse individual and organisational consequences. 


\section{DIFFERENT FORMS OF INTERNATIONAL WORKING}

International commuters and employees utilised on extended business trips

International commuters and extended business trips are widespread modifications of the full-scale expatriation process (Harris et al., 2005; Peppas, 2004). International commuter assignments involve a specific workplace abroad to which employees travel on a regular basis, most often weekly or bi-weekly. While the employee works abroad, spouse and family - if existent - stay at home. Extended business trips, often also termed frequent traveller or flexpatriate assignment (Mayerhofer, Hartmann, Michelitsch-Riedl, \& Kollinger, 2004b), deviate from 'normal' trips in terms of duration or frequency. Individuals do not relocate, but visit their work place abroad during business trips undertaken very often or lasting longer than usual.

The following two examples illustrate both forms of working abroad. In 2004, OMV, the Austrian oil company, bought the majority of shares of Petrom, the national Romanian oil company with roughly 50,000 employees at that time. In the immediate aftermath of the acquisition, about 80 experienced Austrian headquarter managers were expatriated to Romania following the classical expatriation format. However, some key positions were filled through international commuting. For example, between 2004 and 2006 the senior vice president of corporate human resources located at the OMV headquarter in Vienna spent 3 days per week at the operations in Romania. The German 
clothing industry provides an example for extended business trips used for 'quality engineers' dealing with several countries and the local operations in low cost countries. The quality engineers have to secure that the products meet the required standards set by the parent company and are delivered on time. They spend a considerable or most of their working time abroad, yet do not move permanently because they regularly have to be at headquarters to report and receive updated information (see Mayrhofer \& Scullion, 2002).

Compared to classical expatriation, these forms of working internationally have the following consequences for the organisations involved (for a more detailed view see Mayerhofer et al., 2004b). First, they affect a greater number of employees. While classical expatriation often is limited to key positions requiring substantial administrative support and financial resources, both international commuting and extended business trips can be used across a broader spectrum of employees. At the same time, the total cost involved is potentially lower since specific procedures for selection, training, financial incentives etc. are less required or obsolete. Second, both alternative forms offer greater flexibility for the organisation. Duration of the arrangement, geographical scope, or content of work can more easily and on a comparatively short notice be changed. In turn, this promises cost savings and short reaction times. Third, they affect different parts of the organisation. In classical expatriation, HR departments play a key role in all parts of the process. International commuting and extended business trips are less prone to standardised central procedures and large parts of it are handled without HR specialists. This constitutes some risk since some of the issues involved such as handling cultural differences or coping with 
constantly changing work and social environments require HR expertise. Nevertheless, it also helps to simplify the process of working abroad. Fourth, less involvement of HR specialist puts more emphasis on individual employees' abilities to cope with the situation on their own or to get access to supporting resources such as information, coaching, or peer networks (Mayerhofer, Hartmann, \& Herbert, 2004a). Finally, less involvement of HR specialists and central co-ordination poses the danger of greater fragmentation, less consistency over time and less knowledge flow between various parts of the organisation dealing with these forms of working internationally. Individual consequences such as stress, burn-out, different social \& working patterns?

International transferees

Individuals moving from one international assignment to the next are not new for IHRM. In the diplomatic service, for example, they are the rule rather than the exception. In companies operating across national borders, this group traditionally consisted of classical expatriates not returning to their home organisation after their foreign assignment. They were certainly not a large-scale phenomenon and partly seen more as a liability than an asset. Again, the situation has changed considerably over the past decades. Mainly related to an accelerating speed of internationalization, the creation of an international orientation within crucial members of the organisational management team is regarded as essential: "Developing a multicultural, international management is considered to be on of the primary requisites of competing in the global marketplace successfully." (Harvey, Price, Speier, \& Novicevic, 1999b: 39). Increasing 
the number of managers with international work experience and management teams with a mixed cultural background are important measures for achieving this goal.

Two groups of individuals contribute to these efforts. Inpatriate managers are closely familiar with more than one culture due to their personal or job history. Coming from countries other than the home-country organisation, they are assigned to the homecountry on a semi-permanent or even permanent basis (Harvey, Speier, \& Novicevic, 1999a). Global managers take the international career orientation one step further and opt for 'aspatial careers' (Suutari, 2003: 189 ff.). For them, differentiations between home, host or third country designation become meaningless as they are no longer attached to specific countries. Rather, they commit themselves to a longer period of international positions irrespective of the specific country, either by consecutive international positions or interrupted only briefly by their 'return' to a basis, e.g. organisational headquarter. Organisations can use them wherever staffing needs arise worldwide. In terms of their personal career anchors (Schein, 1978), developing management expertise and looking for challenges seem to be crucial (Suutari \& Taka, 2004).

Examples of inpatriates managers abound in European companies enlarging into formerly communist countries in Eastern Europe. Managers of newly acquired companies or founded subsidiaries were transferred for considerably periods of time to headquarter operations. For example, during the late 1990s, Flextronics, a leading global player in the OEM (original equipment manufacturing) business, transferred key people of their newly founded subsidiaries in Hungary to longer established subsidiaries 
to support professional socialization, transfer of cultural values in both directions, and increase the global mindset of its employees. At about the same time, Fluor Corporation, one of the world's largest publicly owned engineering, procurement, construction, and maintenance services companies based in the U.S., reorganised its staff to achieve a greater potential of internationally capable managers. It developed mobile global managers working in multiple offices and facilities worldwide, thus connecting dispersed operations and forming matrix teams (Stanek, 2000).

These forms of working internationally have a number of consequences. First, while inpatriation combines several positive aspects of expatriation and working with locals, some of the problems arising are strikingly similar to classical expatriation. Examples include acting as boundary spanning persons, coping with cultural and/or economic distance between countries involved, stress due to acculturation processes or adapting to the local organisational culture. Although these topics are familiar for IHRM, their concrete form of appearance is new since many of the structural characteristics of inpatriation clearly differs from expatriation, e.g. the relative internal importance of the sending and receiving organisational unit or the ascribed social status of inpatriates. Second, early international assignments are crucial when trying to build a cadre of internationals. A study of Finnish global managers (Suutari, 2003) shows that while roughly half of them had a global orientation from the outset, half of them changed to a long-term international career orientation after their first assignment abroad. Third, inpatriates can be used as 'linking pins' between various parts of the organisations as well as between the organisation and the environment. This contributes to a more strategic global HRM response in a turbulent global environment (Harvey et al., 1999a). 
Self-initiated movers who live abroad but are willing to work for a multinational organisation

Classical expatriation is usually initiated by the organisation. Employees can express their interest in jobs abroad, but by and large, organisational demands determine the 'when', 'where' and 'how'. Self-initiated movers deviate from this pattern. They go abroad on their own initiative and emphasize individual, often diffuse goals when looking for self-initiated work experience (Inkson, Arthur, Pringle, \& Barry, 1997).

Compared to classic expatriates, self-initiated movers are characterised by a number of specifics. Personal agency has been shown to be important in the development of their career attitudes to international mobility. In a longitudinal study about self-initiated movers - full time employees who had graduated from Australian business schools Tharenou (2003) shows that the initial development of receptivity to international careers was driven by a combination of personal agency (beliefs about capability to work in foreign cultures), home barriers (low family influence) and work environment opportunities (a clearly understood international focus shifted receptivity in younger but not older employees). A Finnish study contrasts self-initiated movers with expatriates (Suutari \& Brewster, 2000). Being slightly younger, there are more females and more singles among them. They typically work in a local private company or in international organisations; the organisations they work for are less international and more project based; and they work more frequently on temporary contracts and at lower 
organisational levels with an expert status. Interest in international issues and poor employment situation at home are mentioned more frequently as primary triggers and motives for going abroad. Self-initiated movers typically have no return guarantee and often no plans to return to their home country. Instead, they are more willing to accept another period of working abroad or even a permanent stay abroad. Their compensation levels varies more and they less frequently have access to typical expatriation benefits such as hardship, housing or education allowances and travel insurance.

Self-initiated movers typically fall into two categories. The first group consists of young people looking for a job abroad on their own immediately after finishing their education. As part of a national pattern - "every year, tens of thousands of young Australians and New Zealanders make their pilgrimage to London, as a starting point for what they call, in local vernacular, "the big OE" (overseas experience) - a period of travel, exploration, and personal development" (Inkson \& Myers, 2003: 171) - or individual decision making, they regard their stay abroad as part of a personal development experience that might or might not lead to a longer-term occupational career. The second group consists of more experienced people beyond the establishment phase of their careers.

Self-initiated movers lead to a number of issues for organisational HRM. First, they provide an easily accessible pool of international workforce that can be attracted with comparatively little cost and outside typical expatriation schemes. Second, while they are easily accessible, they usually - at least at the beginning - lack any organisationspecific track record. Hence, all the risks of external recruitment are linked with hiring from this group. Third, personnel planning is difficult since the availability of this group 
is hard to predict in case of organisational demand. Fourth, specific attraction mechanisms and messages (to link into their distinct motivation patterns?) to target these?

Immigrants actively and passively attracted to a national labour market

The opportunity for broader patterns of international resourcing strategies - and types of international working - has increased markedly due to two recent developments:

1. Certain labour markets have themselves become globalised (Ward, 2004), for example, healthcare markets (Clark, Steward, \& Clark, 2006).

2. Levels of international mobility, especially migration, have increased, impacting the domestic HR strategies of firms and offering new opportunities to international firms (Salt \& Millar, 2006).

Historically, the level of mobility within the EU has been low. Before the incorporation of the new accession countries less than $0.5 \%$ of Europe's 350 million citizens moved from one member state to another. EU accession has increased levels of mobility and reduced the need for many organisations to rely on specialised cadres of international employees. The UK and Ireland - together with Sweden - allowed open labour markets, causing significant recruitment effects. 
In the UK, the proportion of domestic employers recruiting from abroad rose from 28 per cent in 2004 (Czerny, 2004) to 38 per cent in 2005. Of those recruiting overseas, 53 per cent expected this activity to increase (CIPD, 2005). HR practitioner discussion about this passive and active attraction of foreign labour has included concerns about disincentives for employers to invest in domestic training; negative reputational impacts on host organisations in terms of shifts in resourcing policy and impacts on donor countries; training for managers in the cultures of immigrant employees and insights into the use of own language versus English language and perceptions of customer service; the requirement for passive, active and strategic recruitment activities; and problems of indirect indiscrimination within selection systems. A number of issues arise from the international migration of talented labour. These include: establishing where professional expertise and technical insight lies; deciding whether initiatives require targeted campaigns or longer term strategic moves to sourcing from specific countries or regions; understanding and establishing base technical competence of recruitees and setting up assessment processes where necessary; considering the ethical and reputational issues associated with campaigns; ensuring infrastructure in local receiving units to handle increasing workforce diversity; and building reputations of receiving units, operations or locations into internationally competitive sites.

In Ireland, the open economic model, in which multinationals have been encouraged to locate production and invest on the basis of European demand and cost competitiveness, has seen attention given to societal impacts of immigration. Barrett, Bergin and Duffy (2006) examined the impact of Irish immigration policy on high and low-skilled wages and levels of GNP per head. Overall high skill policies have been shown to be 
beneficial, but education-occupation discrepancies exist and attention has turned to industrial relations consequences of international mobility, with large scale immigration from Poland and from potential EU applicant countries bringing the voluntarist system of workplace relations under pressure and creating debates about national minimum wage systems (Frawley, 2006).

The Irish experience of complementary high and low skilled immigration has also presented employers with an opportunity to adopt novel global labour supply strategies. Cities such as Dublin or London have become "magnets" for a category of international self-initiated movers, with new support structures being developed to support employers with multicultural workplaces. Sparrow (2007) uses the example of Barclaycard International to demonstrate how the development of a multicultural workforce in one location can be used to seedcorn new models of internationalization. Its call centre in Dublin acted as a platform and nursery for future international expansion, growing from 10 to 360 people from 1997-2006 primarily on the basis of recruiting both immigrants and self-initiated movers in the city. Intended to support non-UK operations, it grew to serve eight countries including Ireland, Italy, Spain, France, Germany, Portugal, Greece, and Botswana. The seed-corning of other overseas locations through the development of protocols to manage a multicultural workforce in Dublin operations, and then the „reexport" of both these protocols and (some of) the people to other operations, was a major component of the strategy to build a platform of people management processes (processes, structures and frameworks) that brought stability, governance and control to newly established overseas operations. Active and passive resourcing strategies targeted at residents of large global cities in Europe have produced a useful mix of immigrant 
and more transient self-initiated movers, capable of assisting effective international working.

The question of effectiveness has seen attention turn to the issue of competencies. For immigrants in employment integration is a significant issue. As with self-initiated movers, personal agency skills have been shown to be important, but they are of a more collective nature. Immigrants have to learn by observation, enabling them to acquire knowledge, attitudes, values, emotional proclivities and competences through the information that is conveyed. They develop three important "agency skills" (Bandura, 2001; 2002): direct personal agency to manage their own lives and bring influence to bear directly on themselves and their own environment; proxy agency skills for those spheres of people's life where they have no direct control over the social and institutional practices that affect everyday life and so rely on others - and must influence others - to act on their behalf and secure personally desired outcomes; and collective agency skills where people act in concert with other people to shape their future by pooling knowledge, skills and resources, forming alliances, and acting in mutual support to secure that which they cannot accomplish on their own.

International employees active in virtual, cross-border teams

With the increase of international collaborations at all hierarchical levels, and through the explosive development of electronic communication media, cross-border, virtual teams abound. These teams face the challenges of working not only across cultures, but 
also across different national offices, often around the globe. For example, 103 companies in a study of McDonough, Kahn, \& Barczak (2001) estimated that $22 \%$ of their product development teams would be distributed globally within the next years. Such international constellations are set up to achieve an international presence whilst reducing expenses for travelling. However, the success of such collaborations is unlikely to be obtained without careful management attention. Managers have to keep in mind that intercultural process losses can be augmented by the difficulties of virtual cooperation - and vice versa.

One of the most persistent problems is that of virtual intercultural communication. To understand the meaning of a message, it is necessary to understand its context to some degree. This is, however, even more the case in high-context cultures, where the larger part of the message is unspoken and can only be understood by knowing the context, such as a Japanese colleague's obligations towards his hierarchical network at home. The potential for misunderstandings is of course increased if communication is via less rich media, such as e-mail. On the other hand, these media can decrease misunderstandings when used for documenting facts or decisions. For these reasons, managers have to ensure that the communication form and pattern is adjusted to the purpose of the communication.

Cultural differences and virtuality can also challenge the quality of interpersonal relationships within the teams (Axtell, Fleck, \& Turner, 2004). Due to the lack of social interactions and background knowledge of the other person, affective trust may be more fragile or harder to develop within virtual teams. There is also a propensity to develop 
separate subgroup identities according to location and nationality, which can make it harder to achieve team identity and cohesion. Team fractures can be further increased by power struggles and by pressures team members experience from their local unit, superiors, or customers (Zimmermann \& Sparrow, 2007).

A fundamental choice therefore has to be made regarding the general approach to dealing with the differences in the team. Janssens and Brett (2006) recommend a ‘fusion' model of international teamworking, by which different cultural approaches should not be equalled out, but respected, coexist, and be used where they are most useful. In contrast, the 'dominant coalition' model' accepts power differentials, leading to the adjustment of one nationality to the dominant nationality, typically the nationality of headquarters, who also speak the common language most fluently. Such adjustment may however be beneficial when it leads to easier coordination and better work results (Zimmermann \& Sparrow, 2007). The discussion of Adler would take too much space. I also wanted to avoid drifting into a review of the whole literature on international team success factors.

Managers can also take a number of preventive actions to avoid process losses. Regular face-to-face meetings are again essential, particularly at the point of launching the teamwork, to build a personal basis for trust. Moreover, systematic teambuilding throughout the team's lifecycle is highly recommended. Setting shared goals, defining clear team roles and interaction rules, as well as a communication structure can help to avoid differential conceptions from the beginning. This can also serve to increase the commitment of the team members to the team as a whole. Overall, international, virtual 
teams will have to be led in a more delegative manner, given that direct control is not possible over the distance. A clear team structure is therefore beneficial. This can include designated subgroup leaders and coordinating 'window' employees (those with the greatest language fluency and intercultural skills). Reviews at regular intervals are more necessary than in co-located teams to monitor the team's performance (DiStefano \& Maznevski, 2000). Careful knowledge management, e.g. through shared data bases should help for shared (team) mental models to develop. Finally, although often neglected, many researchers (Canney-Davison \& Ward, 1999, Hertel, Geister, \& Konradt, 2005) suggest that the disbanding of the team after task completion should be accompanied by celebrating successes and feeding the learning points back to the organization.

Skilled individuals working in geographically remote centres of excellence serving global operations

Multinationals have many strategies at their disposal to address skills shortages in any one national labour market. The development of centres of excellence - sometimes in geographically remote areas - is one option to disseminate organisational learning throughout operations and offshore outsourcing.

Ashton, Brown and Lauder (2008) draw attention to changing assumptions within the IHRM literature as a result of such developments. Briscoe and Schuler (2004) see IHRM as a unique set of activities confined to additional requisite activities, e.g. the 
management of international assignees, and working alongside HR professionals from other countries and adapting HR practices to multicultural and cross-cultural environments. In contrast, they argue, the perspective of Sparrow, Brewster and Harris (2004) suggests that IHRM is confronted with new developments and problems that cannot be adequately handled by treating IHRM in this way. Experimentation through the development of extended talent pipelines, accompanied by market mapping activities, has enabled multinationals to gain control over the attraction and skill formation process. Associated developments in internal organisation designs have then been used to derive greater value out of the deployment of such talent and the knowledge produced. These knowledge management structures include the use of centres of excellence. This latter perspective acknowledges that whilst only a few multinationals have penetrated markets across the globe in that they have the capability to locate, source and manage resources anywhere in the world, nonetheless, they are combining novel skills supply mechanisms and organisation designs to create new forms of international working.

Ashton et al. (2008) question the functionality of this. They collected data on skill formation strategies through interviews with 180 senior managers and chief executive officers in 20 multi-nationals in the UK, USA, Germany, Singapore, South Korea, China and India in the financial services, automobiles and the electronic/ communications sectors between 2004 and 2007. National institutional frameworks and cultures were considered to be primary forces shaping the process of skill formation and the competitive strategies of organisations. Now, the authors argue, it is the ability to manage and deploy skill globally. The process of skill formation is being transformed. 
Multinationals have developed a series of global strategies to exploit differences in the cost of educated labour, with consequent decline in its value. For Brown and Lauder (2006) the process of globalisation has made the link between educated labour and subsequent rewards in the labour market more tenuous. To develop consistency in the management of relationships across the globe, firms are "internalizing" the process of skill creation and the use of these skills. Different components of the supply chain are being modularised and sourced wherever there are cost and business advantages to the company (Berger, 2005) - providing there is a basic infrastructure and education service - and this "commoditization" has spread to knowledge work.

Analyses of the mobility of expertise in multinationals show that within the IT sector at least (Salt \& Millar, 2006), employers have preferred to recruit IT staff from overseas even when skills were still available in the domestic labour market. Highly integrated global internal labour markets, capable of short-term circulation of expertise, have developed. The rise of business process outsourcing models and client pressure to reduce costs have encouraged multinationals to adopt novel skill supply strategies, for example, using their UK bases to host (and rotate) overseas and offshore nationals working at or near end-client sites for short periods of time on development work, backed up by bulk delivery 'campuses' sited in low cost locations. Overseas rotation is used to build up repositories of client and market-specific knowledge in offshore locations, undermining the requirement that overseas recruitment be used for genuine additional new posts. 
Across all of these developments, it might be argued that in one way or another, work moves to where expert staff are and not the other way round. As employers rely more on distributed networks of expertise that can be combined flexibly to create market opportunities, the use of global resourcing models that allow both the injection of critical knowledge into a receiving country and the mining of critical knowledge from domestic markets by overseas suppliers will increase.

\section{CASE EXAMPLE - BEST PRACTICE OF IHRM: ROBERT BOSCH GMBH}

The Robert Bosch Group, who presently employ over 240.000 members, were originally a purely German company. However, Robert Bosch is now spread over 130 countries, with less than $50 \%$ of its workforce located in Germany and more than $70 \%$ of its turnover made outside of Germany. This international distribution was developed strategically to achieve proximity with the large international automotive producers that are the company's main customers, to draw on local expertise, and reduce labour costs. A tight network and close coordination is required between the globally distributed sites. Bosch is therefore a typical example of a company whose employees work internationally at all levels, from top managers to factory workers. The company uses a rather traditional nomenclature of international employees which in practice covers many of the mentioned types: 
(1) Stays abroad that are shorter than 3 months are classified as business trips. These are common amongst employees with border-spanning functions, such as sales, purchasing, or technological advisors for new sites. In practice, business trips range from occasional task-related travels to regular, frequent trips of international commuters.

(2) International, virtual teams exist at all levels. These teams can be tasked with planning, development or production. Typically, not all team members have the same amount of contact with the members of other countries. Rather, one or more 'window' people manage the international interfaces. Business trips to the other site are necessary for transferring know-how, providing technical assistance, and meeting the local customer. Most of the non-German members are assigned to German headquarters at some stage of the collaboration.

(3) International transferees (or expatriates) are classified into (a) long-termers ( 1 to ca. 4 years) and (b) 'delegates' or short-termers (between 3 months and 1 year). The long-termer's contract can be based either on German or on local law, but they always receive their salary from the local site. They are commonly employed with longer-term tasks, such as building up substantial local skill bases. Delegates, in contrast, are paid by their home office and employed for shorter-term projects. Since at least 1990, there is a trend of increasing the number of expatriates moving between subsidiaries and to Germany, as compared to the amount of German expatriates moving to other countries. This serves the strategic purpose of de-centralising the operations and strengthening the international network. 
(4) Internationally working personnel officers are identified as a separate group. They are tasked with selecting, supporting, and coordinating international transferees, teams, and business travellers.

Internationally working employees of all these categories can take part in intercultural training as part of their development plan. Such training thereby serves as a platform for exchanging intercultural know-how. In-house training is offered on general intercultural sensitivity, specific intercultural skills such as regarding negotiation and presentation. Country-specific trainings is conducted for all relevant countries. International teams can request teambuilding workshops and follow-ups throughout their lifecycle. Training is also provided for leading international virtual teams. Intercultural coaching and post merger integration support takes place upon request. For all long-term transferees, places on intercultural pre-departure training and returnee workshops are guaranteed. On their return, expatriates are invited to be trained as country advisors and to join pre-departure trainings in that role. A cycle of intercultural knowledge transfer is thereby created.

At management level, international employees are developed through special programs. In an 'International development program', young leadership potential is selected internationally, sent to Germany for on-the job training for a year, and provided with various training measures. A special talent pool is selected for a 'Management development program' that exists at different national locations. At an early stage of the program, a one-week intercultural training is conducted. At a later stage, trainees of different locations join into a real-life international project over a period of 4 to 6 
months. The task of the project is provided by any of the business areas. Feedback is given by an experienced coach, project sponsors, and top management.

This amount of intercultural development, in particular for non-transferees, is above average when compared within Germany (Konradt, Hertel, \& Behr, 2002: 201). It does not come as a surprise then that the Robert Bosch Group has been at the forefront of intercultural support since the beginning in the early nineties. Its training policy is also embedded in a corporate culture that explicitly names 'cultural diversity' as one of its core values, and a vision stating that additional force shall be drawn from the multitude of national cultures within the company.

\section{FRAGMENTATION OF INTERNATIONAL RESOURCING OR COHERENT INTEGRATION?}

As the examples throughout the text show, firms have recognised the management value of these new forms of international working. However, the degree of their organisational integration is still open to debate. Two aspects seem crucial: integration into organisational routines and into strategic HRM.

First, integration into organisational routines requires signals acknowledging that practices belong to the standard repertoire of an organisation e.g. established practical routines, explicit organisational policies and procedures, or specialised organisational units. Specifically, a clear understanding of the monetary and non-monetary costs 
involved is a crucial test in organisations operating under the dictum of scarce resources.

Given the great variety of forms of international working and the scarce empirical evidence, it is, of course, difficult to generalize. By and large, however, it seems fair to say that while established practical routines have emerged, the integration of these new forms of working into explicit organisational policies and procedure lags behind. Most likely, this is truer for some of the forms discussed such as self-initiated movers and less the case for more established forms such as international commuters or virtual teams.

Especially telling is the awareness of and management of costs, i.e. the difficulty to gain meaningful management information, capability data and insights into discernable motives for the use of each form of working. One has to concede that firms are unlikely to have the data that enables tight cost control of many of these forms of working certainly this will be true of frequent commuters where there are hidden travel and coordination costs. The use of international transferees, virtual teams and self-initiated movers are all tactics (the word is informative) often aimed at reducing costs of international co-ordination.

Yet even here, experience often shows firms that the initial set-up costs are unexpectedly high. This is because integration requires three outcomes: the development of sufficient shared understanding of and alignment with the strategy (sensemaking); trust to ensure effective operation of the new form of international working; and the ability of the form to build understanding in the organisation at large 
(sensegiving). To the extent that firms use these forms of working without dealing with these issues, the initiatives are not driven by strategy but by reaction. Yet, for other forms of international working, such as the use of immigration to address skills shortages and gaps in international capability, or the use of centres of excellence to streamline and develop the provision of capability, it appears that there is a clearer economic and skills supply rationale.

Second, integration into strategic HRM is another important criterion for judging whether we are witnessing fragmentation of international working or not. This includes, most prominently, the link with existing HR core processes and to the strategic goals of the organisation. There needs to be "line of sight" to and from these individuals back into the core HR systems, such as talent management and performance management processes. Ensuring this was difficult even for small elites of centrally-reporting expatriates, and likely will be shown to be even more challenging for some of the forms of working covered here. If any sense of coherence to international strategy and coordination is to be delivered, then two very practical questions can be asked of organisations looking across these forms of working:

1. Do firms know who and where their talent resides within their remote operational centres, cross-border teams and networks, self-initiated movers in third country operations? Most talent management systems have only limited information about relatively small centrally-overseen populations. International experience and expertise is now much more diffuse and distributed amongst these new forms of working. 
2. Even if firms do know where their talent is, do they have a high quality and consistent management process that "touches" these people, or is their management left to the vagaries of over-stretched line management? Do, for example, country HR business partners have any "line of sight" to key individuals, or collective knowledge, that resides within and across these new forms of international management?

We suspect not, but to be fair this assertion has yet to be tested. Regarding the link to the organisation's strategic goals, this is arguably the most weakly developed aspect of the discussed forms of international working. While they grow out of concrete needs and opportunities when facing processes of internationalisation of the organisation and its various input and output markets, currently it is hard to see how these forms of international resourcing are coherently linked to the overall strategy.

\section{THE NEW RESEARCH AGENDA}

This chapter shows that one can not separate out research into new forms of international working from the broader psychological, social, organisational and societal contexts that such patterns of working create. Viewing many of the developments in new forms of international working under a broader academic umbrella with research at different analytical levels would seem to be a fruitful way forward. 
At a micro-level, a common issue that cuts across these new forms of international working is the need to understand both the motivations for individuals to engage in this type of work, and the required attitudes, skills and competencies. Clearly, most of our understanding about this has been based on the study of expatriate success, and to a lesser extent the development of an international mindset. Rather than relying on knowledge about expatriates and global leaders, as a consequence of international resourcing policies, organisations face a new context of intra-cultural diversity. Some recent psychological work has focused specifically on some of the newer forms of international working drawing upon social cognitive career theory to explain how career interests develop and how people successfully function within cultures. This type of research will have some clear practical benefits for selection, assessment and development of many forms of international employees, but especially for those HR functions relying upon more culturally diverse workforces, even in domestic markets. They show the importance of personal agency, also called self-efficacy (Bandura, 1997), collective agency skills, but also the stability of the attitude of receptivity to international careers and its early development. Broadening the perspective, the question of personal and professional identity emerges. Rapid changes between various work locations in different countries and cultures, belonging to a cadre of internationals with little or no attachment to a 'home country' leads to question about how individuals cope with the lack of external structures supporting personal and social identity.

At the meso-level of the organisation, several research issues can be identified. They include questions such as: How (fast) is the management of these new forms of working internationally transformed into standardised HR activities? What effects do a greater 
diversity of the workforce and the existence of a variety of international work forms have on other employees and on organisational processes such as knowledge sharing, strategic alignment or speed of organisational change? How do organisations cope with an increasingly internationally mobile workforce that leaves universities and business schools, ready to take on international positions throughout their careers as 'born or socialised internationals'? In addition, transcending the current focus on firms would seem beneficial. Much research is done in the business context, implicitly meaning large firms. However, new forms of working internationally also frequently occur in organisations such as small and medium sized enterprises (SMEs); nonprofit and nongovernmental organisations (NPOs, NGOs); international organisations belonging to supra-national bodies such as the UN or the EU; newly internationalizing companies working the market on a strictly regional basis as is the case in many EU-border regions. Looking at these organisations can lead to a more refined understanding of varieties of working internationally .

At a macro-level there are some very important changes taking place within the field. From the research covered in this chapter it can be seen that as globalisation progresses, the field of IHRM is both broadening and engaging in a dialogue with other disciplines. For example, Ashton et al. (2008) drew upon both the national business system and IHRM literatures to contextualize the nature of skill supply strategies. This directs attention towards a pressing research need at the macro-level: to unravel the external and societal impact that the development of new internal skills webs has at a national and policy level and concern about the types of knowledge and skills that global HR strategies are delivering. Pointing towards more interdisciplinary research, the study on 
the use of high skilled migrants as a source of international labour by Salt and Millar (2006) discussed earlier has brought perspectives from the field of economic geography into the IHRM literature. In addition, regional studies taking into account the cultural, institutional and natural specifics of world regions and their effects on different forms of working internationally in these regions are needed. The EU with its specific institutional environment or Africa with its high number of developing countries provide examples for this.

Hence, in the years to come, we should expect to see increasing synthesis and reliance upon cross-disciplinary research into the phenomena that are thrown up by new forms of international working.

\section{KEY LEARNING POINTS}

- In addition to expatriation, new forms of working internationally emerge due to global change drivers, e.g. increase in cross-border business transactions and programs sponsoring international mobility; organisational factors such as emerging global internal labour markets; and individual determinants, e.g. changing career and life concepts.

- Major new forms of working internationally include international commuters; employees utilised on long-term business trips; inpatriates managers and permanent cadres of global managers; self-initiated movers transferring abroad on their own initiative; immigrants actively and passively attracted to a national 
labour market; virtual international employees active in cross-border project teams; skilled individuals working in geographically remote centres of excellence serving global operations.

- Organisational and HR expertise only partly cover new forms of working internationally, thus underscoring the importance of individual competencies; while this supports personal development, it also comprises the risk of fragmentation and little coherence

- New forms of working internationally are only partially integrated into organisational routines and strategic HRM; organisations still have a long way to go due to the recency of the phenomenon and the difficulties involved.

- Future research should be interdisciplinary and encompass macro level issues, e.g. the role of various institutional contexts for different forms of working internationally and their management; meso-level issues such as the way and speed of integration of these work forms into HRM; and micro-level aspects, e.g. required competencies and identity issues.

\section{REFERENCES}

Arthur, M. B., \& Rousseau, D. B. (Eds.). 1996. The Boundaryless Career. A New Employment for a New Organizational Era. New York, Oxford: Oxford University Press. 
Ashton, D., Brown, P., \& Lauder, H. 2008. Developing a theory of skills for global HR. In P. R. Sparrow (Ed.), Handbook of International HR Research: Integrating People, Process and Context. Oxford: Blackwell.

Axtell, C. M., Fleck, S. J., \& Turner, N. 2004. Virtual Teams: Collaborating Across Distance. In C. L. Cooper, \& I. T. Robertson (Eds.), International Review of Industrial and Organizational Psychology, Vol. 19: 205-248. Chichester: Wiley.

Bandura, A. 1997. Self-Efficacy: The Exercise of Control. New York.

Bandura, A. 2001. Social cognitive theory: An agentic perspective. Annual Review of Psychology, 52: 1-26.

Bandura, A. 2002. Social Cognitive Theory in Cultural Context. Applied Psychology: An International Review, 51(2): 269-290.

Barrett, A., Bergin, A., \& Duffy, D. 2006. The labour market characteristics and labour market impacts of immigrants in Ireland. The Economic and Social Review, 37(1): $1-26$.

Berger, S. 2005. How we compete. What companies around the world are doing to make in today's global economy. New York: Doubleday.

Briscoe, D. R., \& Schuler, R. 2004. International Human Resource Management Second Edition. London: Routledge.

Brousseau, K. R., Driver, M. J., Eneroth, K., \& Larsson, R. 1996. Career pandemoniums: Realigning organizations and individuals. Academy of Management Executive, 10(4): 52-66.

Brown, P., \& Lauder, H. 2006. Globalisation, Knowledge and the Myth of the Magnet Economy. Globalisation, Societies and Education, 4(1): 25-51. 
Canney-Davison, S., \& Ward, K. 1999. Leading International Teams. Berkshire, UK: McGraw-Hill.

CIPD. 2005. Recruitment, Retention and Turnover Annual Survey Report. London: CIPD.

Clark, P. F., Steward, J. B., \& Clark, D. A. 2006. The globalisation of the labour market for health-care professionals. International Labour Review, 145(1/2): 37-64.

Czerny, A. 2004. UK's foreign trawl continues. People Management, 10(20): 7.

DiStefano, J. J., \& Maznevski, M. 2000. Creating Value with Diverse Teams in Global Management. Organizational Dynamics, 29(1): 45-63.

Dowling, P. E., \& Welch, D. E. 2004. International Human Resource Management (4 ed.). London: Thomson Learning.

Frawley, M. 2006. Irish resistance. People Management, 12(10): 44-45.

GMAC-Global-Relocation-Services. 2005. Global relocation Trends 2005 Survey Report. Woodridge, IL: GMAC.

Guthrie, J. P., Ash, R. A., \& Stevens, C. D. 2003. Are women "better" than men? Personality differences and expatriate selection. Journal of Managerial Psychology, 18(3): 229-243.

Hall, D. T., \& Mirvis, P. 1996. The new protean career: Psychological success and the path with a heart. In D. T. Hall (Ed.), The career is dead - long live the career: 1 - 12. San Francisco: Jossey-Bass.

Harris, H. 2000. New Forms of International Working. Cranfield: Center for Research into the Management of Expatriation.

Harris, H., Brewster, C., \& Erten, C. 2005. Auslandseinsatz, aber wie? Klassisch oder alternative Formen: neueste empirische Erkenntnisse aus Europa und den USA. 
In G. Stahl, W. Mayrhofer, \& T. M. Kühlmann (Eds.), Internationales

Personalmanagement. Neue Aufgaben, neue Lösungen: 275-292. München: Hampp.

Harvey, M., Speier, C., \& Novicevic, M. M. 1999a. The role of inpatriation in global staffing. International Journal of Human Resource Management, 10(3): 459476.

Harvey, M. G., Price, M. F., Speier, C., \& Novicevic, M. M. 1999b. The role of inpatriates in a globalization strategy and challenges associated with the inpatriation process. Human Resource Planning, 12(1): 38-50.

Hertel, G., Geister, S., \& Konradt, U. 2005. Managing virtual teams: A review of current empirical research. Human Resource Management Review, 15: 69-95.

Inkson, K., Arthur, M. B., Pringle, J., \& Barry, S. 1997. Expatriate assignment versus overseas experience: Contrasting models of international human resource development. Journal of World Business, 32(4): 351-368.

Inkson, K., \& Myers, B. A. 2003. "The big OE": Self-directed travel and career development. Career Development International, 8(4): 170-182.

Janssens, M., \& Brett, J. M. 2006. Cultural intelligence in global teams. A fusion Model of collaboration. Group \& Organization Management, 31(1): 124-153.

Konradt, U., Hertel, U., \& Behr, B. 2002. Interkulturelle Management Trainings. Eine Bestandsaufnahme von Konzepten, Methoden und Modalitäten in Deutschland. Zeitschrift fuer Sozialpsychologie, 33(4): 197-207.

Linehan, M., \& Mayrhofer, W. 2005. International Careers and Repatriation. In H. Scullion, \& M. Linehan (Eds.), International Human Resource Management: 131-155. Houndsmills and New York: Palgrave. 
Mayerhofer, H., Hartmann, L. C., \& Herbert, A. 2004a. Career Management Issues for Flexpatriate International Staff. Thunderbird International Business Review, 46(6): 647-666.

Mayerhofer, H., Hartmann, L. C., Michelitsch-Riedl, G., \& Kollinger, I. 2004b. Flexpatriate assignments: a neglected issue in global staffing. International Journal of Human Resource Management, 15(8): 1371-1389.

Mayrhofer, W., \& Scullion, H. 2002. Female Expatriates in international business. Empirical evidence from the German clothing industry. International Journal of Human Resource Management, 13(4): 815-836.

McDonough, E. F., Kahn, K. B., \& Barczak, G. 2001. An investigation of the use of global, virtual and collocated new product development teams. Journal of Product Innovation Management, 18: 110-120.

Mendenhall, M. E., Kühlmann, T. M., \& Stahl, G. 2000. Developing Global Business Leaders: Policies, Processes, and Innovations. New York: Quorum Books.

Peppas, S. C. 2004. Making the Most of International Assignments: A Training Model for Non-resident Expatriates. Journal of American Academy of Business, Cambridge, 5(1/2): 41-46.

Salt, J., \& Millar, J. 2006. International migration in interesting times: The case of the UK. People and Place, 14(2): 14-25.

Schein, E. H. 1978. Career Dynamics: Matching individual and organizational needs. Reading, MA: Addison-Wesley Publishing Company.

Sparrow, P. R. 2007. Globalisation of HR at function level: Four UK-based case studies of the international recruitment and selection process. International Journal of Human Resource Management, 18(5): 144-166. 
Sparrow, P. R., Brewster, C., \& Harris, H. 2004. Globalizing Human Resource Management. London: Routledge.

Stanek, M. B. 2000. The need for global managers: a business necessity. Management Decision, 38(4): 232-244.

Suutari, V. 2003. Global managers: career orientation, career tracks, life-style implications and career commitment. Journal of Managerial Psychology, 18(3): 185-207.

Suutari, V., \& Brewster, C. 2000. Making Their Own Way: International Experience Through Self-Initiated Foreign Assignments. Journal of World Business, 35(4): 417-432.

Suutari, V., \& Taka, M. 2004. Career anchors of managers with global careers. Journal of Management Development, 23(9): 833-847.

Tharenou, P. 2003. The initial development of receptivity to working abroad: Selfinitiated international work opportunities in young graduate employees. Journal of Occupational and Organizational Psychology, 76: 489-515.

Ward, C. 1996. Acculturation. In D. Landis, \& R. S. Bhagat (Eds.), Handbook of intercultural training, 2nd ed.: 124-147. Thousand Oaks et al.: Sage.

Ward, K. 2004. Going global? Internationalization and diversification in the temporary staffing industry. Journal of Economic Geography, 4: 251-273.

Zimmermann, A., \& Sparrow, P. 2007. Mutual adjustment processes in international teams: lessons for the study of expatriation. International Studies in Management and Organization, 37(3). 
